\title{
Synthesis of polyisobutylene-polycaprolactone block copolymers using enzyme catalysis
}

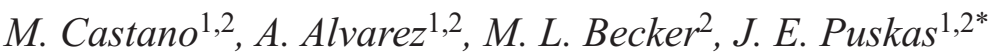 \\ ${ }^{1}$ Department of Chemical and Biomolecular Engineering, The University of Akron, 44325 Akron, USA \\ ${ }^{2}$ Department of Polymer Science, The University of Akron, 44325 Akron, USA
}

Received 21 December 2015; accepted in revised form 12 March 2016

\begin{abstract}
The synthesis of poly(isobutylene- $b$ - $\varepsilon$-caprolactone) diblock and poly( $\varepsilon$-caprolactone- $b$-isobutylene- $b$ - $\varepsilon$-caprolactone) triblock copolymers was accomplished using a combination of living carbocationic polymerization of isobutylene (IB) with the ring-opening polymerization (ROP) of $\varepsilon$-caprolactone ( $\varepsilon$-CL). OH-PIB-allyl was prepared by living carbocationic polymerization of IB initiated with 1,2-propylene oxide/ $\mathrm{TiCl}_{4}$ followed by termination with allyltrimethylsilane. Hydroxyl telechelic HO-PIB-OH was obtained by living IB polymerization initiated by 2,4,4,6-tetramethyl-heptane-2,6$\mathrm{diol} / \mathrm{TiCl}_{4}$, termination with allyltrimethylsilane and subsequent thiol-ene click reaction with mercaptoethanol. The structure of the hydroxyl PIBs was confirmed by ${ }^{1} \mathrm{H}$ NMR (proton Nuclear Magnetic Resonance spectroscopy). OH-PIB-allyl and HO-PIB-OH were then successfully used as macroinitiators for the polymerization of $\varepsilon$-CL catalyzed by Candida antarctica Lipase B (CALB), yielding poly( $\varepsilon$-caprolactone- $b$-isobutylene) diblock and poly( $\varepsilon$-caprolactone- $b$-isobutylene- $b$ - $\varepsilon$-caprolactone) triblock copolymers, respectively. Differential Scanning Calorimetry (DSC), Transition Electron Microscopy (TEM) and Atomic Force Microscopy (AFM) demonstrated that the amorphous PIB and the semicrystalline PCL block segments phase separated, creating nanostructured phase morphology.
\end{abstract}

Keywords: polymer synthesis, enzyme catalysis, block copolymers, polyisobutylene, polycaprolactone

\section{Introduction}

The design of novel macromolecular architectures is a continuous focus in polymer science. Many of these architectures, such as block copolymers, possess unique properties, which make them interesting candidates for special applications in nanotechnology and biomedical materials. Controlled ring-opening polymerization (ROP) of cyclic esters, such as lactide, glycolide, cyclic carbonate, and/or $\varepsilon$-caprolactone $(\varepsilon-C L)$, have received significant attention due to the good mechanical properties, degradation behavior and biocompatibility of the resulting polymers [1-3]. Polyisobutylene (PIB) has been combined with materials widely used for biomedical applications (polyacrylates and -methacrylates, polysiloxanes, polylactones, polyurethanes, poly(ethylene oxide), and poly (vinyl alcohol)), and some devices that use PIB-based materials are approved by the Food and Drug Administration (FDA) [4-6]. One of the most relevant combinations is poly(styrene- $b$-isobutylene- $b$-styrene) (SIBS). SIBS is a very soft, transparent material resembling silicone rubber, with superior mechanical properties. It is used as a drug-eluting coating of coronary stents [6-8]. PIB is not degradable under biological conditions, however, its copolymers can be. Block copolymers of PIB with L-lactide [9] and pivalolactone [10] have been synthesized from primary hydroxyl functionalized PIBs and metal-containing activators. It was found that the blocks had phase-separated morphologies, and the crystallization behavior of the polylactide and polypivalolactone was influenced by the presence of the PIB blocks. However, 
we found only two papers discussing the synthesis of PIB-PCL block copolymers [11, 12]. Both papers used telechelic HO-PIB-OH macroinitiators obtained by multistep processes, and triethyl aluminum or $\mathrm{HCl} \cdot \mathrm{Et}_{2} \mathrm{O}$ catalyst. The first paper concentrated on structural analysis without investigating the phase morphology of the products [11]. The second paper reported microphase-separation based on Differential Scanning Calorimetry (DSC) that found two transitions: $T_{\mathrm{g}}=-60^{\circ} \mathrm{C}$ for the PIB segment and $T_{\mathrm{m}}=$ $60^{\circ} \mathrm{C}$ for the PCL block [12].

This paper reports the facile synthesis of a poly(isobutylene- $b$ - $\varepsilon$-caprolactone) diblock and poly( $\varepsilon$-caprolactone- $b$-isobutylene- $b$ - $\varepsilon$-caprolactone) triblock copolymers using PIB-OH and HO-PIB-OH macroinitiators [13-15], and ROP of $\varepsilon-C L$ catalyzed by Candida antarctica lipase B (CALB). Enzyme-catalyzed ROP [16-21] is one of the most promising tools and avoids the use of organo-metallic catalysts ( $\mathrm{Zn}, \mathrm{Al}, \mathrm{Sn}$ or $\mathrm{Ge}$ ), which are known to be cytotoxic to cellular systems and are often difficult to remove from polymeric products [2]. Gross and Hillmyer used anionically synthesized monohydroxyl-functional polybutadiene of various molecular mass $\left(M_{\mathrm{n}} \sim\right.$ 2600-19000 g/mol) to initiate the ROP of $\varepsilon-\mathrm{CL}$ and pentadecalactone catalyzed by CALB to make diblock copolymers. However, the products contained 10-30 wt $\%$ homoPCL after methanol precipitation, so they developed a fractionation method to purify the diblocks [19]. Tang and coworkers [20, 21] used hydroxyl- and ester-functionalized polyoctadiene to initiate ROP of $\varepsilon$-CL and $\omega$-pentadecalactone using CALB, but did not investigate the phase morphology of the resulting block copolymers. PIB-containing block copolymers have never been synthesized using CALB-catalyzed ROP of lactones. We report conditions leading to pure di- and triblock copolymers.

\section{Experimental section}

\subsection{Materials}

HO-PIB-allyl $\left(M_{\mathrm{n}}=4300 \mathrm{~g} / \mathrm{mol}, \bigoplus_{\mathrm{M}}=1.21\right)[18]$ and HO-PIB-OH $\left(M_{\mathrm{n}}=4100 \mathrm{~g} / \mathrm{mol}, \bigoplus_{\mathrm{M}}=1.2\right)[14,15]$ macroinitiators were synthesized by recently reported facile new methodologies. $\varepsilon$-caprolactone $(\varepsilon-\mathrm{CL}$, Sigma Aldrich, $97 \%)$, methylene chloride $\left(\mathrm{CH}_{2} \mathrm{Cl}_{2}\right.$, $\geq 99.8 \%$, EMD Chemicals) and toluene (Sigma Aldrich, 99\%) were dried over $\mathrm{CaH}_{2}$ (95\%, Aldrich)) and distilled under vacuum. Methanol $(\mathrm{MeOH}$,
99.8\%, Fisher Scientific) was used as received. Lipase B from Candida antarctica immobilized on microporous acrylic resin (20 wt\% CALB, Novozyme 435, Sigma Aldrich), deuterated chloroform $\left(\mathrm{CDCl}_{3}\right.$, $99.8 \%$, Chemical Isotope Laboratories) were used as received.

\subsection{Procedures}

\subsubsection{Synthesis of}

poly(isobutylene- $b$ - $\varepsilon$-caprolactone)

A solution of HO-PIB-allyl $\left(0.18 \mathrm{~g}, 8.05 \cdot 10^{-3} \mathrm{~mol} / \mathrm{L}\right)$ and dry toluene $(5.0 \mathrm{~mL})$ were transferred via syringe under dry $\mathrm{N}_{2}$ atmosphere into a flask containing immobilized CALB (75 mg, 20\% CALB, $\left.4.33 \cdot 10^{-4} \mathrm{~mol} / \mathrm{L}\right)$. The suspension, as well as a separate flask containing $\varepsilon-\mathrm{CL}$, was equilibrated for $15 \mathrm{~min}$ at the reaction temperature $\left(70^{\circ} \mathrm{C}\right)$. Thereafter, $\varepsilon-\mathrm{CL}$ $(0.2 \mathrm{~g}, 0.35 \mathrm{~mol} / \mathrm{L})$ was transferred to the reaction flask via syringe under dry $\mathrm{N}_{2}$ atmosphere to start the polymerization. After $24 \mathrm{~h}$ reaction time the reaction mixture was cooled to room temperature and CALB was removed by filtration. The polymer was precipitated in methanol and dried under vacuum for $24 \mathrm{~h}$ at room temperature (yield $0.235 \mathrm{~g}, \varepsilon$-CL conversion $28 \%)$.

\subsubsection{Synthesis of poly( $\varepsilon$-caprolactone- $b$ - isobutylene- $b$ - $\varepsilon$-caprolactone)}

A solution of HO-PIB-OH $\left(0.090 \mathrm{~g}, 8.13 \cdot 10^{-3} \mathrm{~mol} / \mathrm{L}\right)$ and dry toluene $(2.5 \mathrm{~mL})$ were transferred via syringe under dry $\mathrm{N}_{2}$ atmosphere into a flask containing immobilized CALB - $(40 \mathrm{mg}, 20 \%$ CALB, $\left.4.45 \cdot 10^{-4} \mathrm{~mol} / \mathrm{L}\right)$. The suspension, as well as a separate flask containing $\varepsilon$-CL, was equilibrated for $15 \mathrm{~min}$ at the reaction temperature $\left(70^{\circ} \mathrm{C}\right)$. Thereafter, $\varepsilon$-CL $(0.2 \mathrm{~mL}, 0.67 \mathrm{~mol} / \mathrm{L})$ was transferred to the reaction flask via syringe under dry $\mathrm{N}_{2}$ atmosphere to start the polymerization. After $24 \mathrm{~h}$ reaction time the reaction mixture was cooled to room temperature and CALB was removed by filtration. The polymer was precipitated in methanol and dried under vacuum for $24 \mathrm{~h}$ at room temperature (yield $0.14 \mathrm{~g}, \varepsilon-\mathrm{CL}$ conversion $25 \%$ ).

\subsection{Characterization}

\subsubsection{Size exclusion chromatography (SEC)}

The molecular mass and molecular mass distribution $\left(\oslash_{\mathrm{M}}\right)$ of the polymers were determined by SEC con- 
sisting of a Waters 515 HPLC Pump, a Waters 2487 Dual Absorbance UV Detector (UV), a Wyatt OPTILAB DSP Interferometric Refractometer (RI), a Wyatt DAWN EOS multi-angle light scattering detector (LS), a Wyatt ViscoStar viscometer (VIS), a Wyatt QELS quasi-elastic light scattering instrument (QELS), a Waters 717 plus autosampler and 6 Styragel ${ }^{\circledR}$ columns (HR6, HR5, HR4, HR3, HR1 and H0.5). The columns were thermostated at $35^{\circ} \mathrm{C}$ and THF, continuously distilled from $\mathrm{CaH}_{2}$, was used as the mobile phase at a flow rate of $1 \mathrm{~mL} / \mathrm{min}$. The results were analyzed by using the ASTRA software (Wyatt Technology). Block copolymer $\mathrm{dn} / \mathrm{dc}$ was calculated based on the weight fraction and $\mathrm{dn} / \mathrm{dc}$ of the individual components; $\mathrm{PCL}=0.053$ [22] and PIB $=0.108$ [23]. The results agreed with data obtained assuming $100 \%$ mass recovery.

\subsubsection{Nuclear Magnetic Resonance (NMR) spectroscopy}

${ }^{1} \mathrm{H}$ NMR spectra were recorded on a Varian Mercury$500 \mathrm{NMR}$ spectrometer in $\mathrm{CDCl}_{3}$. The resonance at $\delta=7.27 \mathrm{ppm}\left({ }^{1} \mathrm{H}\right.$ NMR $)$ was used as internal reference. Spectra were acquired with 128 transients and a relaxation time of $5 \mathrm{sec}$.

\subsubsection{Differential scanning calorimetry (DSC)}

DSC was carried out on a TA Q2000 instrument. $5 \mathrm{mg}$ of the sample was subjected to heating/cooling cycles at $10^{\circ} \mathrm{C} / \mathrm{min}$ in the temperature range of -100 to $150^{\circ} \mathrm{C}$. Nitrogen atmosphere was used to minimize thermal degradation of the polymers. $T_{\mathrm{g}}$ and $T_{\mathrm{m}}$ were calculated as the mean value between the onset and end point temperatures of the second cycle.

\subsubsection{Optical microscopy}

Optical images were collected with an Olympus BX51 optical microscope using reflected light.

\subsubsection{Transmission electron microscopy (TEM)}

TEM was carried out on a Philips Tecnai 12 instrument at an accelerating voltage of $120 \mathrm{kV}$. Thin films were prepared on a carbon coated glass surface by spin coating one drop of a $1 \%$ polymer solution in THF. The carbon coated glass surface with the spin coated copolymer was immersed into a distilled water bath. The polymeric film along with the carbon layer floated onto the water surface, and then was picked up by clean TEM copper grids (400 mesh, SPI). Before TEM observation, the samples on the grids were annealed for $5 \mathrm{~min}$ at $70^{\circ} \mathrm{C}$ and then $15 \mathrm{~h}$ at $40^{\circ} \mathrm{C}$. The samples were stained with $1 \% \mathrm{OsO}_{4}$.

\subsubsection{Atomic Force Microscopy (AFM)}

AFM images were taken using a Veeco Instruments Multimode AFM with a Nanoscope IV controller, operated in the tapping-mode with height and phase images collected simultaneously. Silicon cantilevers with a nominal resonance frequency of $170 \mathrm{kHz}$ (Aspire CT170R) were used, with typical medium-light tapping forces as characterized by a $2.0 \mathrm{~V}$ free amplitude and a $1.6 \mathrm{~V}$ set point amplitude.

\section{Results and discussion \\ 3.1. Synthesis of poly(isobutylene- $b-\varepsilon-$ caprolactone) diblock}

The enzyme-catalyzed ROP of $\varepsilon$-CL was initiated using the HO-PIB-allyl macroinitiator $\left(M_{\mathrm{n}}=\right.$ $4300 \mathrm{~g} / \mathrm{mol}$ with $\bigoplus_{\mathrm{M}}=1.21$ ) as shown in Figure 1. In this case [monomer]/[OH] $\sim 40$ was used based on Storey's previous report [11]. Higher ratios were tried but did not yield clean diblocks.

Figure 2 shows the ${ }^{1} \mathrm{H}$ NMR spectrum of PIB- $b$-PCL. The resonances at $\delta=5.04 \mathrm{ppm}$ (f) and $\delta=5.77 \mathrm{ppm}$ (e) belong to the allylic protons of the HO-PIB-allyl macroinitiator. Signals for structural analysis included those at 3.68 and 4.33 (h, J $6.5 \mathrm{~Hz},-\mathrm{CH}_{2}-\mathrm{OH}$ ), due to the methylene protons of PCL chain-end units and resonances at $4.11 \mathrm{ppm}(\mathrm{g})$ and $2.32 \mathrm{ppm}(\mathrm{m})$, due to the methylene protons in the PCL repeat unit. The $M_{\mathrm{n}}$ of the poly( $\varepsilon$-caprolactone) block was calculated from the ratio of the integral of the methylene protons of the repeat unit of PCL (g) at $\delta=4.23 \mathrm{ppm}$ and the methylene proton of the allyl end group of<smiles>C=CCC(C)(C)CC(C)(C)CC(C)CC(C)CC(C)OC(=O)CCCCCO</smiles>

Figure 1. CALB catalyzed ROP of $\varepsilon$-CL using allyl-PIB-OH as macroinitiator. [HO-PIB-allyl $]=8.05 \cdot 10^{-3} \mathrm{~mol} / \mathrm{L}$, $[\varepsilon-\mathrm{CL}]=$ $0.35 \mathrm{~mol} / \mathrm{L} ;[\mathrm{CALB}]=4.33 \cdot 10^{-4} \mathrm{~mol} / \mathrm{L}$. 


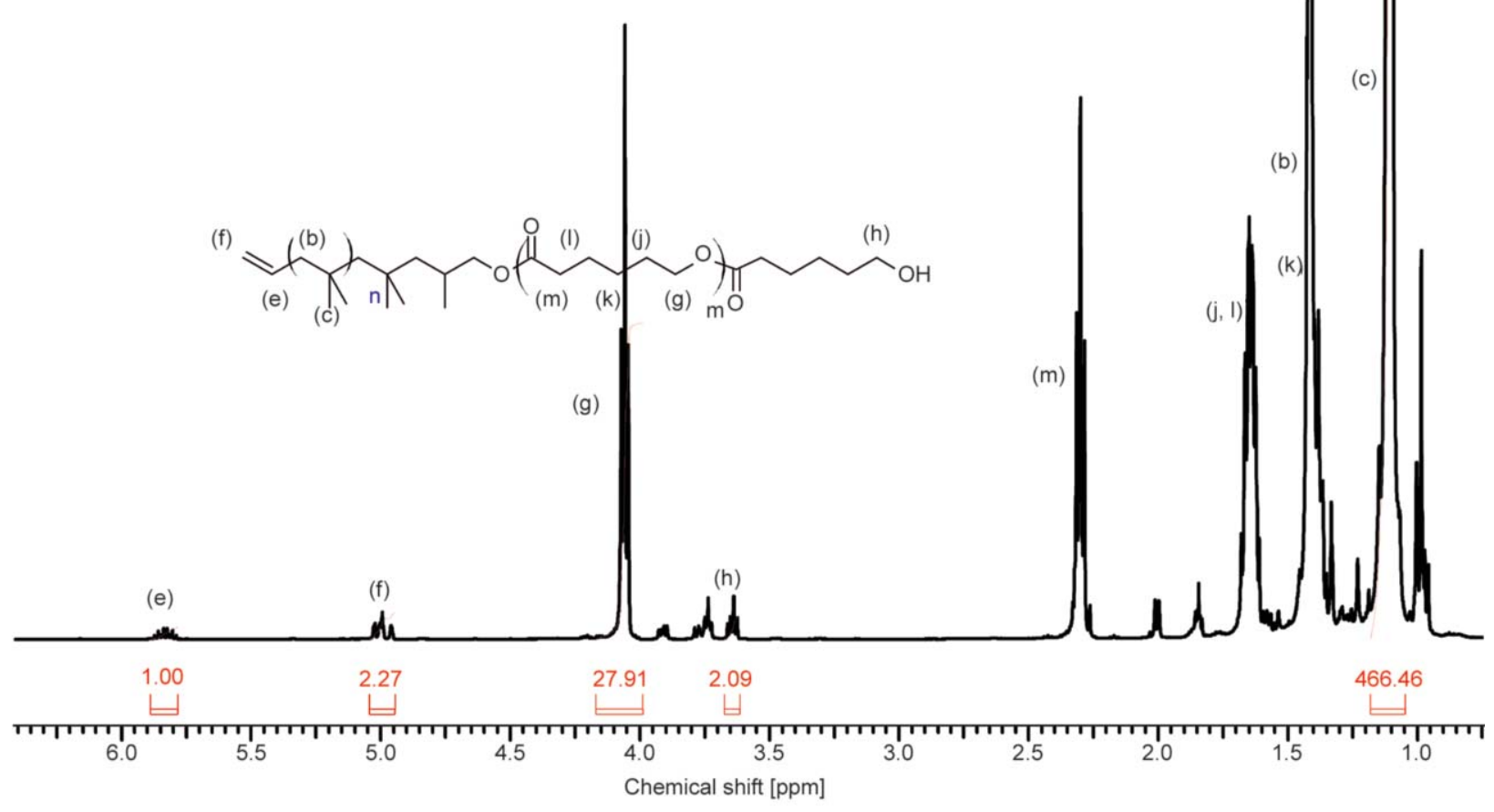

Figure 2. ${ }^{1} \mathrm{H}$ NMR spectrum of PIB- $b$-PCL

HO-PIB-allyl (e) at $\delta=5.77 \mathrm{ppm}$ as $M_{\mathrm{n}}=1590 \mathrm{~g} / \mathrm{mol}$. Thus the total diblock molecular weight is $M_{\mathrm{n}}=$ $5890 \mathrm{~g} / \mathrm{mol}$, corresponding to $26.8 \mathrm{wt} \%$ PCL. Figure 3 shows the SEC traces of the macroinitiator and the diblock copolymer (PIB-b-PCL).

Relative to the starting HO-PIB-allyl $\left(M_{\mathrm{n}}=\right.$ $4300 \mathrm{~g} / \mathrm{mol})$, the SEC RI traces of PIB- $b$-PCL diblock

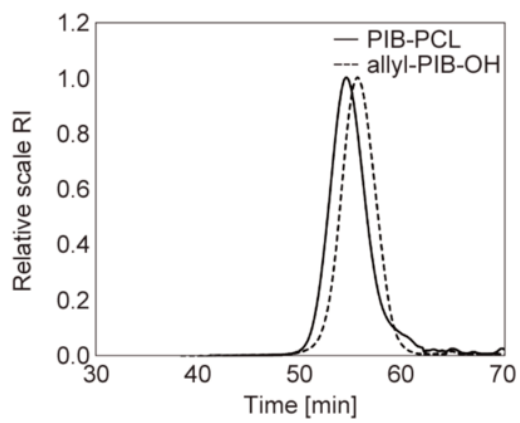

Figure 3. SEC traces of HO-PIB-allyl and PIB- $b$-PCL copolymer shifted to higher molecular mass and the molecular mass distribution remained narrow. The $M_{\mathrm{n}}=6100 \mathrm{~g} / \mathrm{mol}$ and $\bigoplus_{\mathrm{M}}=1.26$ were determined by SEC using $\mathrm{d} n / \mathrm{d} c=0.093$. This corresponds to a $\mathrm{PIB}_{4300}-b-\mathrm{PCL}_{1800}$ structure (29.5 wt \% PCL), which is in good agreement with the NMR data.

\subsection{Synthesis of poly( $\varepsilon$-caprolactone- $b$ - isobutylene- $b$ - $\varepsilon$-caprolactone) triblock}

Figure 4 shows the triblock synthesis. HO-PIB-OH $\left(M_{\mathrm{n}}=4100 \mathrm{~g} / \mathrm{mol}, \bigoplus_{\mathrm{M}}=1.2\right)$ was used as a macroinitiator.

Figure 5 shows the ${ }^{1} \mathrm{H}$ NMR spectrum of PCL-PIBPCL. The signal of the methylene protons of the HOPIB-OH macroinitiator (h) at $3.77 \mathrm{ppm}$ disappeared. Signals for structural analysis included those at 3.68 and 4.33 (h, J $6.5 \mathrm{~Hz},-\mathrm{CH}_{2}-\mathrm{OH}$ ), due to the meth-

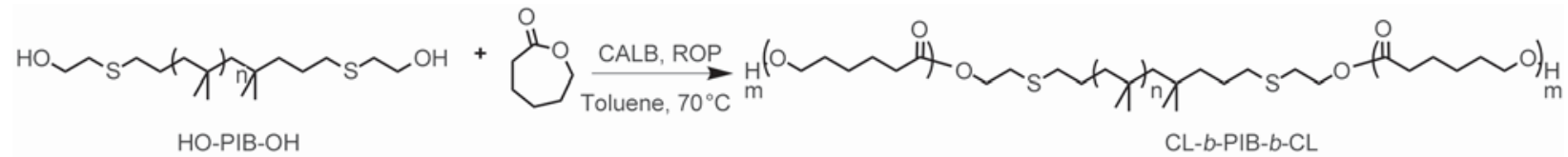

Figure 4. Synthesis of PCL-PIB-PCL. $[\mathrm{HO}-\mathrm{PIB}-\mathrm{OH}]=8.13 \cdot 10^{-3} \mathrm{~mol} / \mathrm{L},[\varepsilon-\mathrm{CL}]=0.67 \mathrm{~mol} / \mathrm{L} ;[\mathrm{CALB}]=4.45 \cdot 10^{-4} \mathrm{~mol} / \mathrm{L}$. 


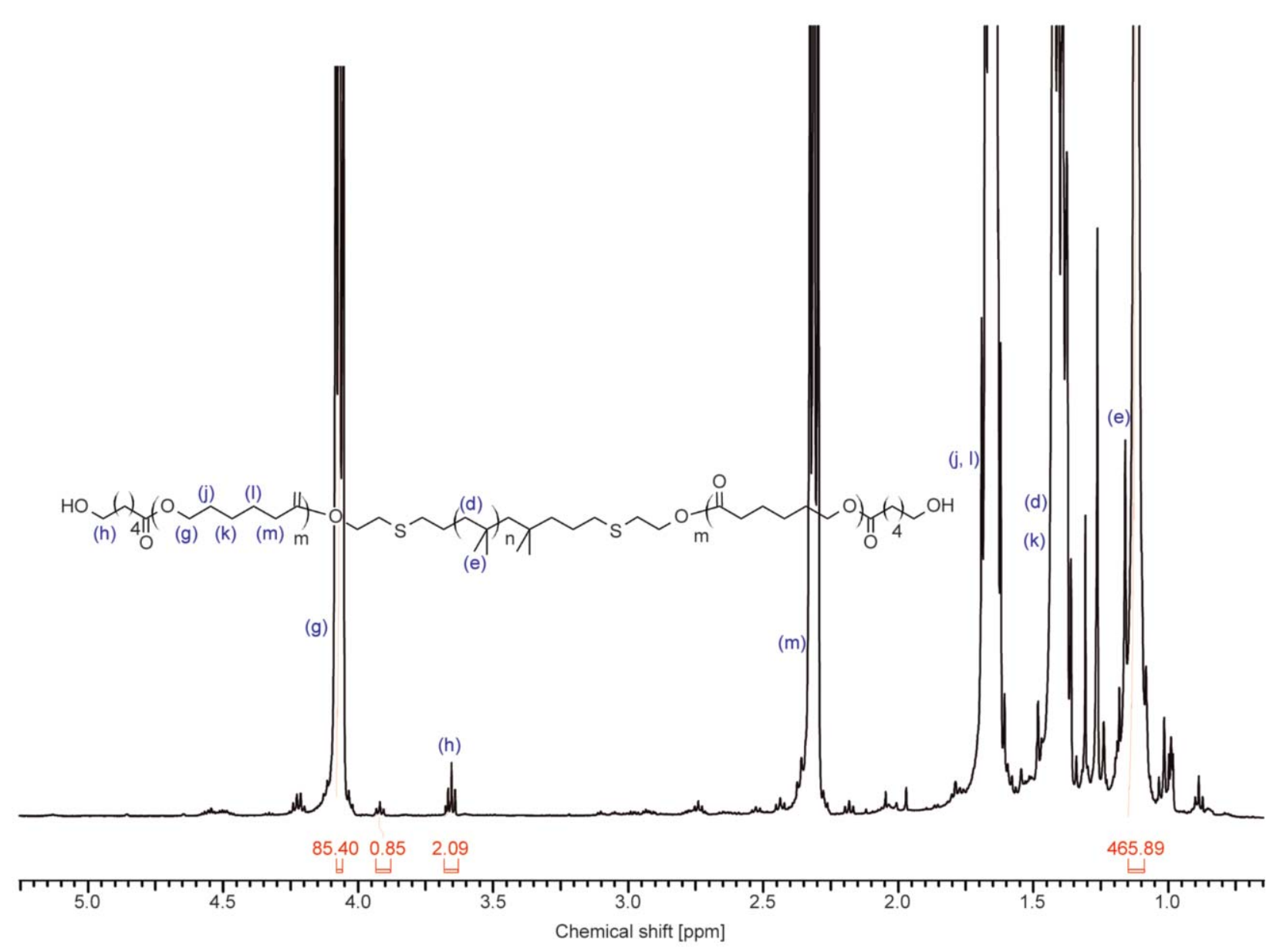

Figure 5. ${ }^{1} \mathrm{H}$ NMR spectrum PCL-PIB-PCL

ylene protons of PCL chain-end units and resonances at $4.11 \mathrm{ppm}(\mathrm{g})$ and $2.32 \mathrm{ppm}(\mathrm{m})$, due to the methylene protons in the PCL repeat unit. The proton resonances at $\delta=1.13 \mathrm{ppm}(\mathrm{e})$ and $\delta=1.45 \mathrm{ppm}$ (d) correspond to the methyl and methylene protons, respectively, of the repeat unit of PIB.

$M_{\mathrm{n}}=2200 \mathrm{~g} / \mathrm{mol}$ was calculated for the PCL blocks from the ratio of the integral of the methylene protons of the repeat unit of PCL (h) at $\delta=3.99$

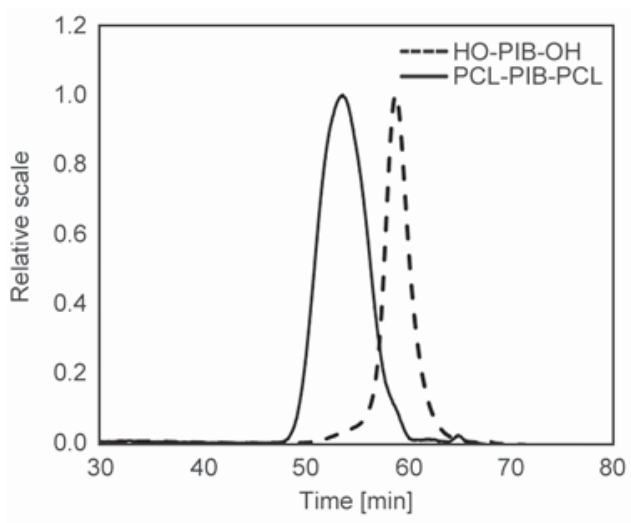

Figure 6. SEC traces of HO-PIB-OH and PCL- $b$-PIB- $b$-PCL
$4.11 \mathrm{ppm}$ and the methyl protons of the repeat unit of PIB (e), and using $M_{\mathrm{n}}=4090 \mathrm{~g} / \mathrm{mol}$ for the starting HO-PIB-OH. Thus the PIB center block is flanked on either side by PCL outer blocks, giving a structure of $\mathrm{PCL}_{2200}-b-\mathrm{PIB}_{4090}-b-\mathrm{PCL}_{2200}$ and $52.8 \mathrm{wt} \% \mathrm{PCL}$ content. The SEC traces are shown in Figure 6. SEC analysis yielded $M_{\mathrm{n}}=8400 \mathrm{~g} / \mathrm{mol}\left(\bigoplus_{\mathrm{M}}=1.48\right)$, in good agreement with the NMR data.

\subsection{Phase morphology}

DSC thermograms are presented in Figure 7.

The diblock copolymer exhibited the $T_{\mathrm{g}}$ of the amorphous rubbery PIB segment at $T_{\mathrm{g}}=-70.1^{\circ} \mathrm{C}$ and another transition at $45.9^{\circ} \mathrm{C}$. The DSC of the triblock showed the PIB $T_{\mathrm{g}}$ at $-67.2^{\circ} \mathrm{C}$ and a very sharp transition at $51.3^{\circ} \mathrm{C}$ with a shoulder at $55.1^{\circ} \mathrm{C} \cdot T_{\mathrm{g}}=-60^{\circ} \mathrm{C}$ and $T_{\mathrm{m}}$ ranging between $59-64^{\circ} \mathrm{C}$ were reported in the literature for PCL [24]. In our case, the $T_{\mathrm{g}}$ transition for the PCL blocks was barely detectable at $-60.2{ }^{\circ} \mathrm{C}$ These observations clearly indicate microphase-separation in the block copolymers between 
the soft PIB phase and the PCL hard phases. The sharp and prominent high temperature transition in the DSC indicates that the PCL blocks in the triblock have very high crystalline fractions. This may be due to con-

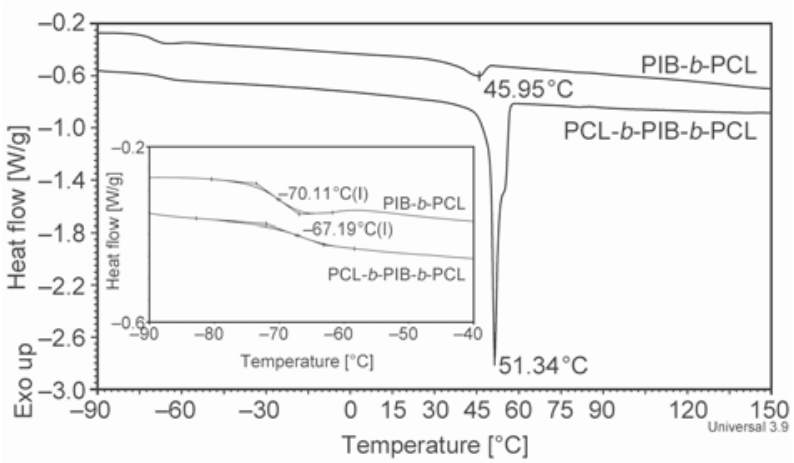

Figure 7. DSC thermograms of PIB- $b$-PCL and PCL- $b$-PIB$b$-PCL

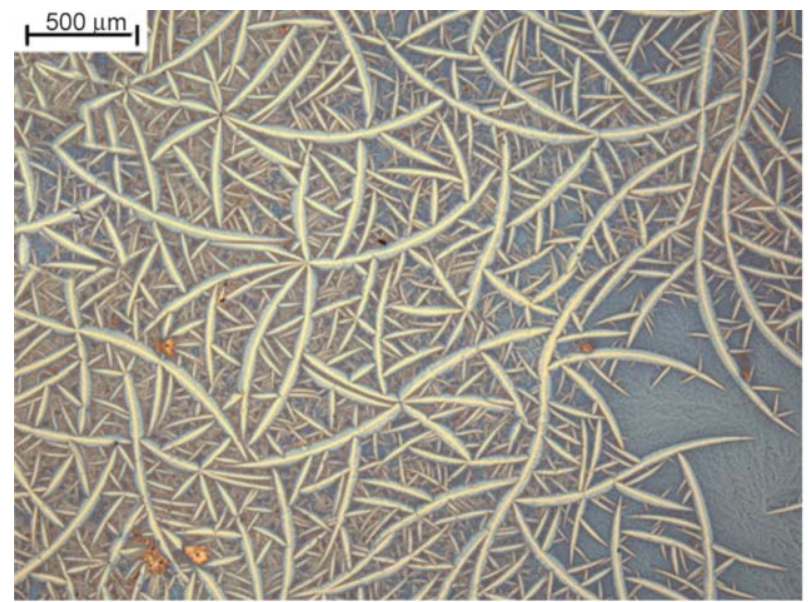

a) finement by the PIB phases. We will investigate this phenomenon in more detail.

Figures $8 \mathrm{a}$ and $\mathrm{b}$ shows the optical images of the diblock and triblock copolymers. We have no explanation for these strange patterns: crystalline PCL normally displays the well-known 'Maltese cross' pattern [25].

The AFM images (Figures 9) are also unusual and need further investigation.

The TEM of the diblock in Figure 10a did not show clear features. The TEM of the triblock copolymer in Figure 10b indicates a lamellar structure, but the lamella thickness appears to be too large. This will require more detailed investigations. However, all images show phase-separation.

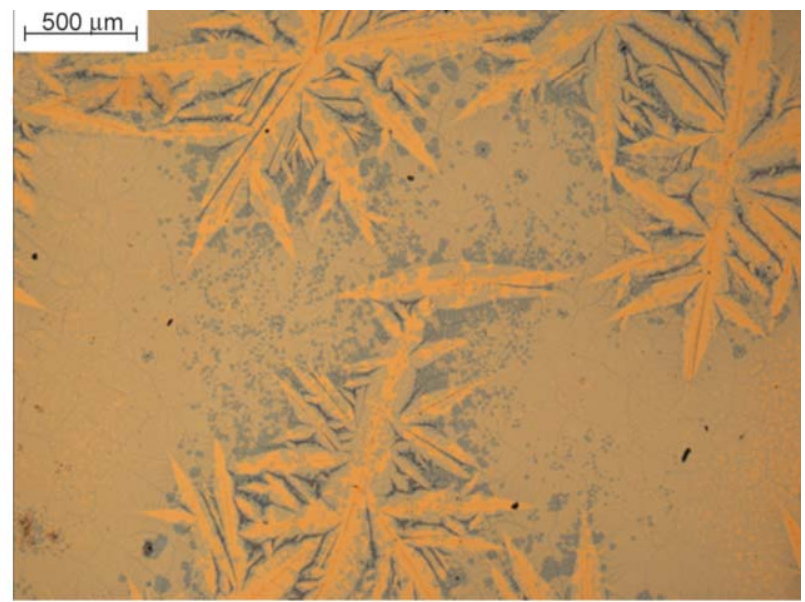

b)

Figure 8. Optical images of (a) PIB- $b$-PCL and (b) PCL- $b$-PIB- $b-P C L$

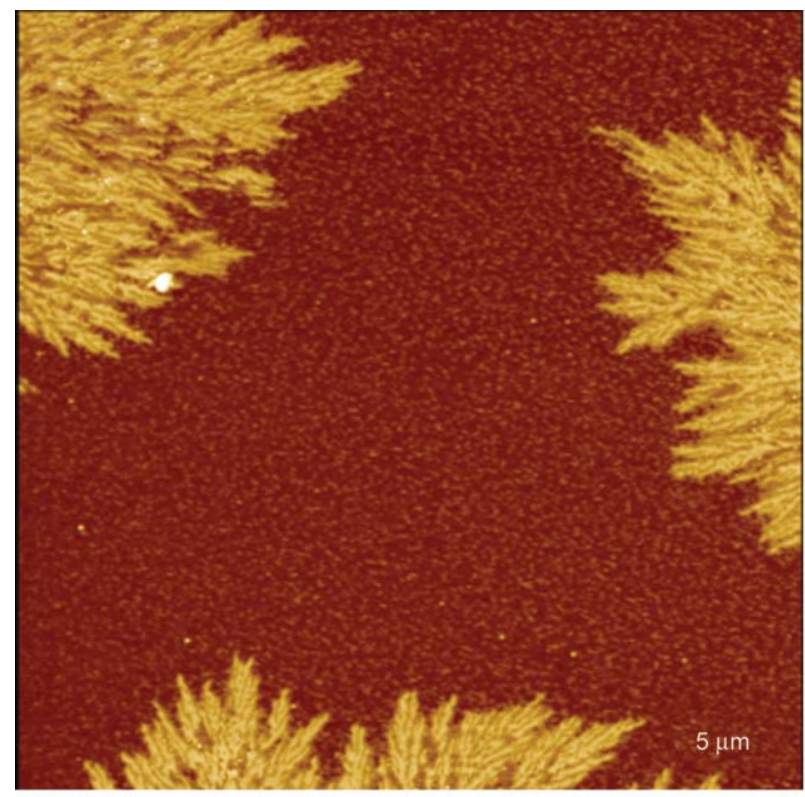

a)

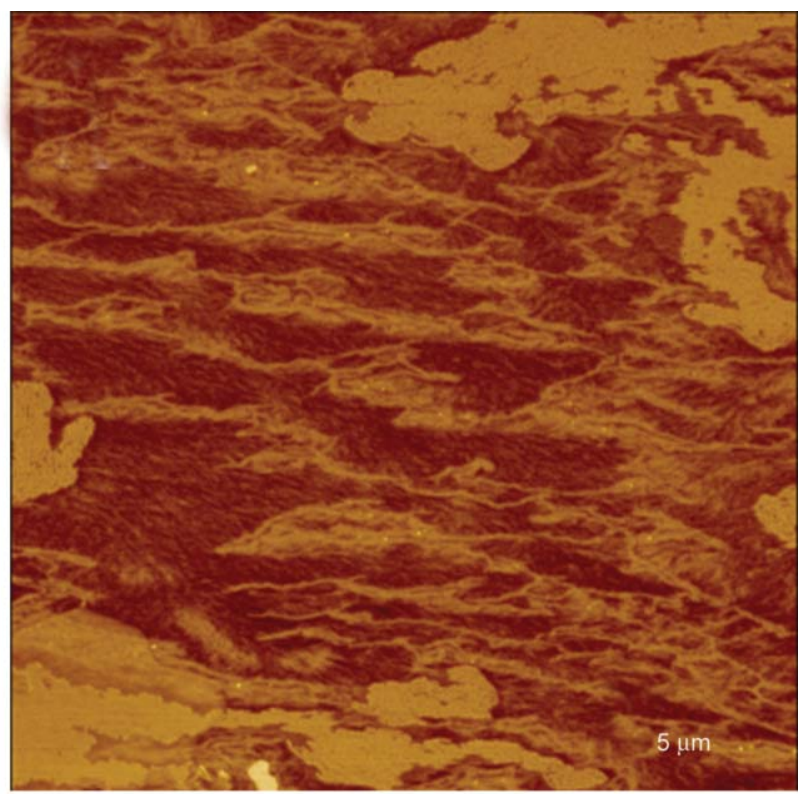

b)

Figure 9. AFM images of (a) PIB- $b$-PCL and (b) PCL- $b$-PIB- $b$-PCL 


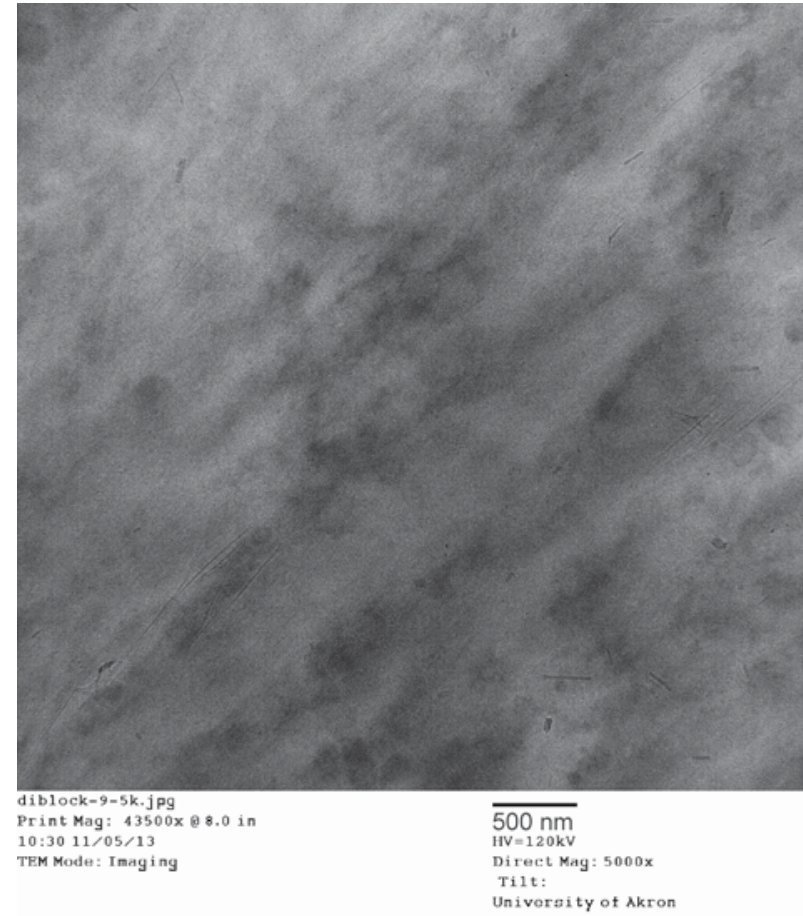

a)

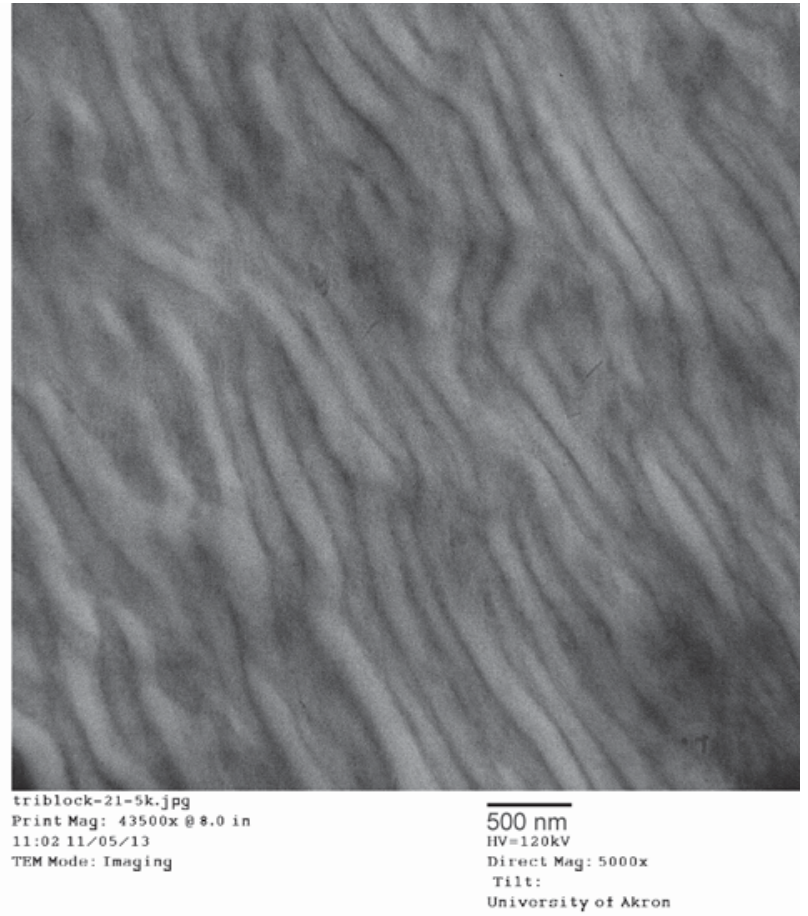

b)

Figure 10. TEM images of (a) PIB- $b$-PCL and (b) PCL- $b$-PIB- $b$-PCL

\section{Conclusions}

The combination of carbocationic and enzymatic polymerization yielded PIB- $b$-PCL and PCL- $b$-PIB$b$-PCL. The use of enzyme catalysis resulted in the metal-free synthesis of poly(caprolactone) blocks, which normally requires the use of tin or other transition metals, which are difficult to remove. This methodology can be expanded to the synthesis of other cyclic monomers to yield functional biomaterials containing degradable polyester blocks. The phase morphology of the blocks requires further investigation.

\section{Acknowledgements}

This material is based upon work supported by the National Science Foundation under DMR-0804878 and the Ohio Board of Regents. We wish to thank The Ohio Board of Regents and The National Science Foundation for funds used to purchase the NMR (CHE-0341701 and DMR-0414599) and MS (CHE-1012636 and DMR-0821313) instruments used in this work.

\section{References}

[1] Coates G. W., Hillmyer M. A.: A virtual issue of macromolecules: 'Polymers from renewable resources'. Macromolecules, 42, 7987-7989 (2009).

DOI: $10.1021 / \mathrm{ma} 902107 \mathrm{w}$
[2] Albertsson A-C., Varma I. K.: Recent developments in ring opening polymerization of lactones for biomedical applications. Biomacromolecules, 4, 1466-1486 (2003). DOI: $10.1021 / \mathrm{bm} 034247 \mathrm{a}$

[3] Kamber N. E., Jeong W., Waymouth R. M., Pratt R. C., Lohmeijer B. G. G., Hedrick J. L.: Organocatalytic ringopening polymerization. Chemical Reviews, 107, 58135840 (2007). DOI: $10.1021 / \mathrm{cr} 068415 \mathrm{~b}$

[4] Puskas J. E., Chen Y., Dahman Y., Padavan D.: Polyisobutylene-based biomaterials. Journal of Polymer Science Part A: Polymer Chemistry, 42, 3091-3109 (2004). DOI: $10.1002 /$ pola.20114

[5] Pinchuk L., Wilson G. J., Barry J. J., Schoephoerster R. T., Parel J-M., Kennedy J. P.: Medical applications of poly(styrene-block-isobutylene-block-styrene) ('SIBS'). Biomaterials, 29, 448-460 (2008).

DOI: 10.1016/j.biomaterials.2007.09.041

[6] Puskas J. E., Muñoz-Robledo L. G., Hoerr R. A., Foley J., Schmidt S. P., Evancho-Chapman M., Dong J., Frethem C., Haugstad G.: Drug-eluting stent coatings. Wiley Interdisciplinary Reviews: Nanomedicine and Nanobiotechnology, 1, 451-462 (2009). DOI: $10.1002 /$ wnan. 38

[7] Puskas J. E., Hoerr R. A.: Drug release from novel rubbery coatings. Macromolecular Symposia, 291-292, 326-329 (2010).

DOI: $10.1002 / \mathrm{masy} .201050538$ 
[8] Ranade S. V., Miller K. M., Richard R. E., Chan A. K., Allen M. J., Helmus M. N.: Physical characterization of controlled release of paclitaxel from the TAXUS ${ }^{\mathrm{TM}}$ Express $^{2 \mathrm{TM}}$ drug-eluting stent. Journal of Biomedical Materials Research Part A, 71, 625-634 (2004).

DOI: $10.1002 / \mathrm{jbm}$. a.30188

[9] Sipos L., Zsuga M., Deák Gy.: Synthesis of poly(L-lactide)-block-polyisobutylene-block-poly(L-lactide), a new biodegradable thermoplastic elastomer. Macromolecular Rapid Communications, 16, 935-940 (1995). DOI: 10.1002/marc.1995.030161209

[10] Kwon Y., Faust R., Chen C. X., Thomas E. L.: Synthesis and characterization of poly(isobutylene- $b$-pivalolactone) diblock and poly(pivalolactone- $b$-isobutylene$b$-pivalolactone) triblock copolymers. Macromolecules, 35, 3348-3357 (2002).

DOI: $10.1021 / \mathrm{ma} 011739 \mathrm{~b}$

[11] Storey R. F., Brister L. B., Sherman J. W.: Structural characterization of poly( $\varepsilon$-caprolactone $)$ and poly $(\varepsilon-$ caprolactone- $b$-isobutylene- $b$ - $\varepsilon$-caprolactone) block copolymers by MALDI-TOF mass spectrometry. Journal of Macromolecular Science Part A: Pure and Applied Chemistry, 38, 107-122 (2001).

DOI: $10.1081 / \mathrm{MA}-100103337$

[12] Kim M. S., Faust R.: Synthesis of poly( $\varepsilon$-caprolactone$b$-isobutylene) diblock copolymer and poly( $\varepsilon$-caprolactone- $b$-isobutylene- $b$ - $\varepsilon$-caprolactone) triblock copolymer. Polymer Bulletin, 48, 127-134 (2002).

DOI: 10.1007/s00289-002-0019-X

[13] Iván B., Kennedy J. P.: Living carbocationic polymerization. XXX. One-pot synthesis of allyl-terminated linear and tri-arm star polyisobutylenes, and epoxy- and hydroxy-telechelics therefrom. Journal of Polymer Science Part A: Polymer Chemistry, 28, 89-104 (1990). DOI: $10.1002 /$ pola. 1990.080280107

[14] Albarran A. A., Silantyeva E., Seo K. S., Puskas J. E.: Synthesis of functionalized polyisobutylenes using the propylene epoxide/ $/ \mathrm{TiCl}_{4}$ initiating system. Polymer Chemistry, 5, 4710-4714 (2014). DOI: $10.1039 / C 4 P Y 00363 B$

[15] Castano M., Becker M. L., Puskas J. E.: New method for the synthesis of fully aliphatic telechelic $\alpha, \omega$-dihydroxy-polyisobutylene. Polymer Chemistry, 5, 54365442 (2014). DOI: $10.1039 /$ C4PY00569D

[16] Kumar A., Gross R. A.: Candida antartica Lipase B catalyzed polycaprolactone synthesis: Effects of organic media and temperature. Biomacromolecules, 1, 133 138 (2000). DOI: $10.1021 / \mathrm{bm} 990510 \mathrm{p}$
[17] Bankova M., Kumar A., Impallomeni G., Ballistreri A., Gross R. A.: Mass-selective lipase-catalyzed poly( $\varepsilon$-caprolactone) transesterification reactions. Macromol-ecules, 35, 6858-6866 (2002). DOI: $10.1021 / \mathrm{ma} 0202282$

[18] Kobayashi S., Uyama H., Kimura S.: Enzymatic polymerization. Chemical Reviews, 101, 3793-3818 (2001). DOI: $10.1021 / \mathrm{cr} 9901211$

[19] Kumar A., Gross R. A., Wang Y., Hillmyer M. A.: Recognition by lipases of $\omega$-hydroxyl macroinitiators for diblock copolymer synthesis. Macromolecules, 35, 7606-7611 (2002).

DOI: $10.1021 / \mathrm{ma} 020060 \mathrm{k}$

[20] Xiang S., Zhang Q., Zhang G., Jiang W., Wang Y., Zhou H., Li Q., Tang J.: Facile synthesis of block copolymers by tandem ROMP and eROP from esters precursors. Biomacromolecules, 15, 3112-3118 (2014).

DOI: $10.1021 / \mathrm{bm} 500723 \mathrm{k}$

[21] Jiang W., An N., Zhang Q., Xiang S., Bai Z., Han H., Li X., Li Q., Tang J.: One-pot combination of eROP and ROMP for the synthesis of block copolymers. Macromolecular Chemistry and Physics, 216, 2107-2114 (2015).

DOI: $10.1002 / \mathrm{macp} .201500313$

[22] Baśko M., Kubisa P. Polyester oligodiols by cationic AM copolymerization of L,L-lactide and $\varepsilon$-caprolactone initiated by diols. Journal of Polymer Science Part A: Polymer Chemistry, 45, 3090-3097 (2007). DOI: $10.1002 /$ pola.22065

[23] Puskas J. E., Chen Y., Kulbaba K., Kaszas G.: Effect of the molecular weight and architecture on the size and glass transition of arborescent polyisobutylenes. Journal of Polymer Science Part A: Polymer Chemistry, 44, 1770-1776 (2006).

DOI: $10.1002 /$ pola.21273

[24] Wunderlich B., Bodily D. M., Kaplan M. H.: Theory and measurements of the glass-transformation interval of polystyrene. Journal of Applied Physics, 35, 95-102 (1964).

DOI: $10.1063 / 1.1713105$

[25] Chen H-L., Li L-J., Ou-Yang W-C., Hwang J. C., Wong W-Y.: Spherulitic crystallization behavior of poly $(\varepsilon-$ caprolactone) with a wide range of molecular weight. Macromolecules, 30, 1718-1722 (1997). DOI: $\underline{10.1021 / \mathrm{ma} 960673 \mathrm{v}}$ 